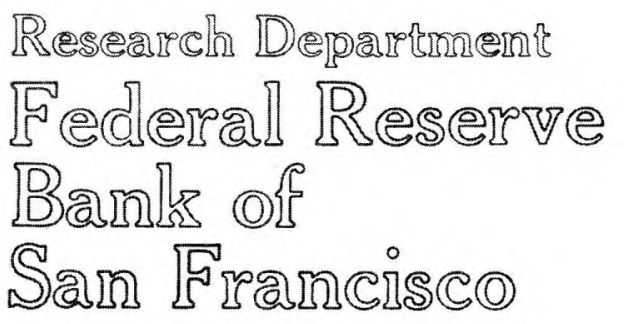

October 29, 1976

\title{
Forecasting Interest Rates
}

The textbook theory of money and banking tells us that the Federal Reserve controls the supply of reserves to the banking system and that the Fed may, if it wishes, influence the price of these reserves (the Fed funds rate) by changing the reserve supply. If, for example, the Fed injects large additional quantities of reserves into the banking system, reserves will be more readily available and the Fed funds rate will come down.

For several reasons, interpreting real-world changes in the Fed funds rate by means of the simple textbook relationship can be a treacherous endeavor. In particular, the funds rate in the real-world is set in a dynamic environment rather than in a static textbook environment. Within this dynamic environment, both sides of the market are concerned not just with the present funds rate, but with future interest rates as well. Interest-rate forecasts play an essential role in describing the market for bank reserves, because these forecasts can help determine the behavior both of member banks and of the Federal Reserve itself.

\section{Banker's problem}

From a banker's point of view, guessing the future path of interest rates is more important than looking at the present rate. A high present interest rate, even an unexpectedly high rate, is water over the dam. The banker's success or failure depends upon his ability to judge the future path of interest rates and to act upon his judgment.

In evaluating the future course of interest rates, the banker must begin by forecasting the path of the economy, including such key variables as GNP and inflation, and by judging the impact of these variables upon the demand for bank loans and other assets. Going further, he must use this information to form a judgment about the likely response of monetary policy to changes in economic variables. While there is an immense body of literature on forecasting GNP and inflation, and any number of economic consultants available to help in this enterprise, the prediction of the Fed's response to the economy, in contrast, depends upon a variety of imponderables, such as the ability of policymakers to reach their long-run and short-run goals in the current financial and political milieu.

In this world of great uncertainty, therefore, the banker must occasionally grasp at straws. If the funds rate should rise, for example, the banker may form the opinion that this rising trend of rates will continue. And if, as has often happened, the banker decides in this case to treat the new higher level of rates as though it represented a bargain price for cash-with even 
Opinions expressed in this newsletter do not

necessarily reflect the views of the management of the Federal Reserve Bank of San Francisco, nor of the Board of Governors of the Federal Reserve System.

higher rates yet to come-he may then increase his demand for reserves. This may lead to a turn of events unknown in the money and banking texts. An increase in interest rates may spawn an expansion in the bank's short-run demand for new cash and, if the expectation of rising rates is shared by the banker's customers, a rise in the demand for bank loans as well.

\section{Hazards of forecasting}

Several recent historical episodes illustrate the effects of these interest-rate forecasts. Few economists thought at the time that the high interest rates of mid-1974 would be consistent with the rapid growth in loan demand of that same period. Quite possibly, the loan demand of early 1974 reflected hedging by bank customers, as they stocked up on loans to avoid the higher rates they expected in the last half of the year. By the same token, many economists would have forecast stronger credit demand in the ensuing two years, as interest rates tumbled to recessionary lows.

These episodes suggest a certain pattern of errors in business fore- casts of interest rates. If interest rates initially are lower than expected, they may remain lower than expected for a considerable period. But when rates start back up again, the effect on market psychology may be sufficient to drive them even higher.

Weekly changes in the money supply increasingly have come to dominate the average banker's forecasts of future levels of the funds rate. An unexpected increase in the money supply, for example, inspires an increase in the demand for bank reserves, as bankers persuade themselves that the Fed will tighten policy to keep money-supply growth in check. However, this increase in demand itself works to put upward pressure upon the funds rate, quite apart from any Federal Reserve restrictiveness. Indeed, to offset this upward pressure on rates, the Fed may expand the supply of reserves as interest rates move upward. This behavior leads not to a decline in the funds rate, as the textbooks indicate, but rather to a perverse combination of increasing reserves and money growth along with a rising funds rate. 


\section{Fed's problem}

The dynamics of banker response to changing interest rates creates problems for the Fed as well as for the banking system. The Fed would like to use its supply of reserve assets to influence the economy in a predictable way, through such key transmission mechanisms as the cost of business capital goods and the supply of credit to bank borrowers. But the central bank's decision to allow interest rates to drift upward may produce any one of a host of possible bank responses, depending upon what the average banker thinks will happen in the future.

Financial markets react so dramatically to changes in interest rates in part because market makers regard such changes as the key indicator of the Fed's intentions. If bankers did not respond so dramatically to changes in rates, the Fed's larger role in influencing the pace of economic activity might be easier. In that case, bankers possibly would be less likely to expect each increase in interest rates to be followed by further increases.

Kurt Dew

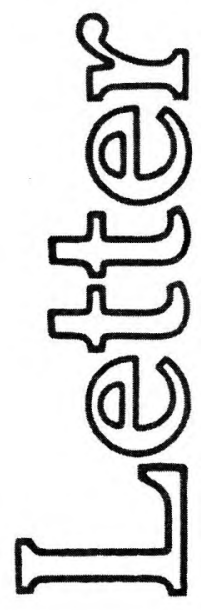

Copies are now available of the summer issue of the Federal Reserve Bank of San Francisco's Economic Review. Under the theme of "Financial Markets and Uncertainty," the issue contains analyses of variable-rate home mortgages, the impact of inflation on capital-market efficiency, debt-equity ratios in financial markets, and the shifting relationship of money demand and GNP. This publication is designed for financial analysts, college students and teachers. For those not on the mailing list, copies may be obtained from the Public Information Section, Federal Reserve Bank of San Francisco, P.O. Box 7702, San Francisco 94120.
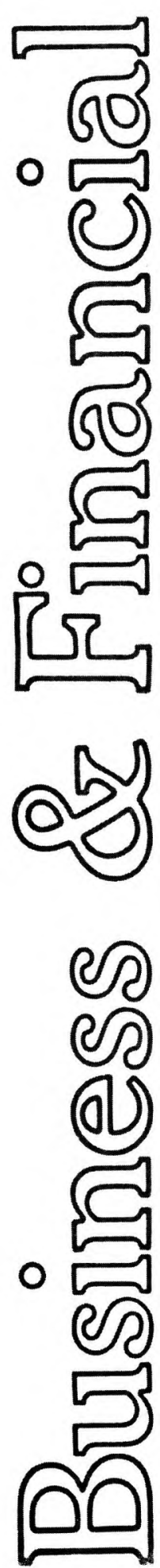


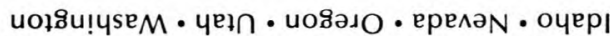

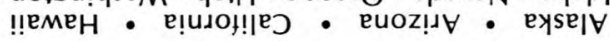

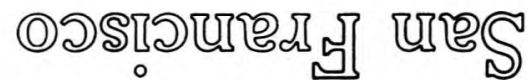

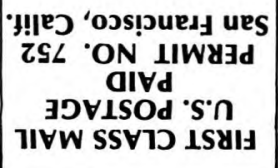

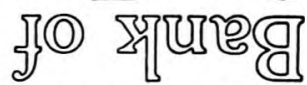

(2)

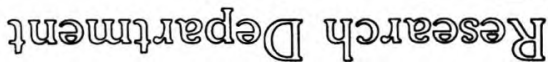

BANKING DATA-TWELFTH FEDERAL RESERVE DISTRICT

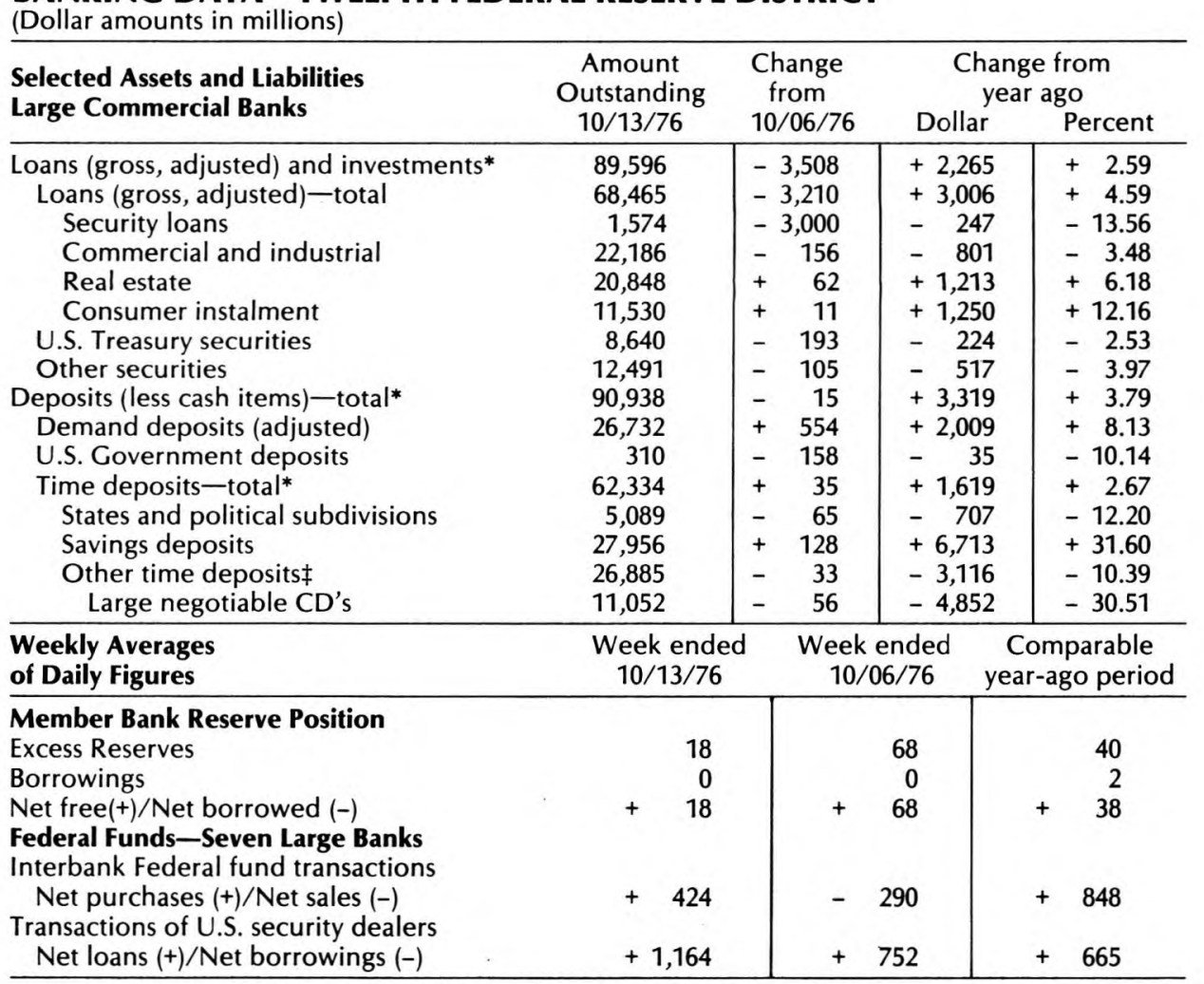

*Includes items not shown separately. łIndividuals, partnerships and corporations.

Editorial comments may be addressed to the editor (William Burke) or to the author. . . .

Information on this and other publications can be obtained by calling or writing the Public Information Section, Federal Reserve Bank of San Francisco, P.O. Box 7702, San Francisco 94120. Phone (415) 544-2184. 